\title{
Viroids and prions
}

(potato spindle tuber disease/scrapie/proteinaceous infectious particles/infectious RNA)

\section{T. O. Diener*, Michael P. McKinley ${ }^{\dagger}$, and Stanley B. Prusiner ${ }^{\dagger}$}

*Plant Virology Laboratory, Plant Protection Institute, Agricultural Research Service, U.S. Department of Agriculture, Beltsville, Maryland 20705; and †Departments of Neurology and of Biochemistry and Biophysics, University of California, San Francisco, California 94143

Contributed by Theodor O. Diener, June 4, 1982

\begin{abstract}
Viroids are small "naked" infectious RNA molecules that are pathogens of higher plants. The potato spindle tuber viroid (PSTV) is composed of a covalently closed circular RNA molecule containing 359 ribonucleotides. The properties of PSTV were compared with those of the scrapie agent, which causes a degenerative neurological disease in animals. PSTV was inactivated by ribonuclease digestion, psoralen photoadduct formation, $\mathrm{Zn}^{2+}$-catalyzed hydrolysis, and chemical modification with $\mathrm{NH}_{2} \mathrm{OH}$. The scrapie agent resisted inactivation by these procedures, which modify nucleic acids. The scrapie agent was inactivated by proteinase $K$ and trypsin digestion, chemical modification with diethylpyrocarbonate, and by exposure to phenol, $\mathrm{NaDodSO}_{4}, \mathrm{KSCN}$, or urea. PSTV resisted inactivation by these procedures, which modify proteins. Earlier evidence suggested that the scrapie agent is smaller than PSTV. Its small size seems to preclude the presence of a genome coding for the protein(s) of a putative capsid. The properties of the scrapie agent distinguish it from both viroids and viruses and have prompted the introduction of the term "prion" to denote a small proteinaceous infectious particle that resists inactivation by procedures that modify nucleic acids.
\end{abstract}

For more than three decades the molecular structure of the scrapie agent has remained elusive. Its remarkable resistance to ionizing and ultraviolet radiations $(1,2)$ suggested that, if the agent contained a nucleic acid to direct its replication, then this genome might be considerably smaller than the genomes of conventional viruses. Target size. calculations have given molecular weight estimates ranging from 64,000 to 150,000 (3).

In 1972, one of us called attention to the fact that these target size values, as well as other properties of the scrapie agent (such as its high resistance to heating, its apparent resistance to proteases, its inability to elicit an immune response from its host, and the absence of virus-like particles in infected tissue) were all compatible with the hypothesis that the agent could have a molecular structure akin to that of the then newly discovered plant viroids (4).

The viroid concept was based on properties of the infectious agent responsible for the potato spindle tuber disease (5). This agent was shown to be an unencapsidated, autonomously replicating, low molecular weight RNA and thus to differ fundamentally from viruses $(5,6)$.

Since then, the molecular structure of viroids has been elucidated to a large extent $(7,8)$. Extensive regions of intramolecular base complementarity result in the formation of collapsed circles and hairpin structures that appear as doublestranded rod-like molecules by electron microscopy $(9,10)$. Both linear and covalently closed circular viroid molecules have been found $(7,10)$. The complete nucleotide sequences of several viroids are known (11-13).

No proteins are associated with purified potato spindle tuber

The publication costs of this article were defrayed in part by page charge payment. This article must therefore be hereby marked "advertise ment" in accordance with 18 U. S. C. $\$ 1734$ solely to indicate this fact. viroid (PSTV), and incubation of crude extracts from infected leaves with proteases alters neither the infectivity nor the sedimentation properties of the infectious agent (6).

Efforts to verify viroid-like properties of the scrapie agent have been fruitless. Two groups have failed to isolate infectious nucleic acid from brain homogenates of scrapie-infected animals $(14,15)$, and claims of a low molecular weight DNA component essential for the expression of infectivity $(16,17)$ have not been confirmed (18).

Recent progress in the purification and molecular characterization of the scrapie agent has provided convincing evidence that the agent contains a hydrophobic protein that is essential for the expression of infectivity $(19,20)$, whereas, even in highly enriched preparations of the scrapie agent, a requirement for nucleic acid has not been demonstrated (21). The results of these recent investigations of the scrapie agent appear to place it outside the realm of viroids and have led to the introduction of the term "prion" (21). Prions are small proteinaceous infectious particles that resist inactivation by nucleic acid-modifying procedures.

Here we describe the results of a more detailed comparison of the properties of the scrapie agent in highly enriched preparations with those of purified PSTV. We report that the two infectious agents fundamentally differ from one another with respect to a number of important additional criteria.

\section{MATERIALS AND METHODS}

Sources of Infectious Agents. The scrapie agent was adapted to hamsters as described $(19,22)$; it was in its eighth passage when used in the present work. PSTV was propagated in and isolated from tomato (Lycopersicon esculentum Mill. cv. Rutgers) plants, as described (23). Cucumber mosaic virus (CMV) RNA was a gift from J. M. Kaper (U.S. Dept. of Agriculture, Beltsville, MD).

Chemicals. $\mathrm{NaDodSO}_{4}$ was obtained from British Drug House (Poole, England) or from Bio-Rad, and zinc nitrate and common reagents (analytical grade) were from Baker Chemical. RNase A and DNase I were purchased from Worthington, proteinase $\mathrm{K}$ from Beckman, and diethylpyrocarbonate $\left(\mathrm{Et}_{2} \mathrm{PC}\right)$ from Sigma. 4'-Aminomethyl-4,5', 8-trimethylpsoralen hydrochloride (AMT) was a gift of John Hearst (Univ. of California, Berkeley, CA).

Partial Purification of the Pathogens. The scrapie agent from hamster brain was partially purified as described in ref. 20 . Fraction $\mathrm{E}_{6}$, prepared by electrophoresis through agarose gels in the presence of Sarkosyl, was used in all experiments. In this fraction, the scrapie agent was enriched $\approx 100$-fold with respect to protein as compared to homogenates.

Abbreviations: AMT, 4'-aminomethyl-4,5',8-trimethylpsoralen; CMV, cucumber mosaic virus; $\mathrm{Et}_{2} \mathrm{PC}$, diethylpyrocarbonate; PSTV, potato spindle tuber viroid. 
PSTV was partially purified as described in ref. 23. A resuspended and dialyzed $2 \mathrm{M} \mathrm{LiCl}$-precipitated fraction was used in all experiments. Aside from PSTV and some minor tomato RNA constituents, this fraction consisted primarily of tRNA and $5 \mathrm{~S}$ rRNA (23).

Bioassays. The infectivity titer of the scrapie agent was determined by measuring the incubation times from inoculation to onset of illness and to death $(19,22)$. Weanling female hamsters (LVG/LAK) were purchased from Charles River Breeding Laboratories and were inoculated intracerebrally with $50 \mu \mathrm{l}$ of suspension at designated dilutions.

PSTV was assayed by inoculating cotyledons of small Rutgers tomato plants with 1:10 dilutions of inoculum (23). A previously described "infectivity index" was computed on the basis of incubation period before symptom expression and severity of symptoms (24).

\section{RESULTS}

$\mathrm{Et}_{2} \mathrm{PC}$ is an electrophile that readily reacts with electron-rich nucleophiles having an unshared pair of electrons (25). The reaction yields a carbethoxylated adduct. $\mathrm{Et}_{2} \mathrm{PC}$ rapidly carbethoxylates proteins but reacts slowly with single-stranded nucleic acids and even more slowly with double-stranded nucleic acids (26).

Recent investigations have shown that in highly enriched preparations the scrapie agent is almost completely inactivated upon reaction with $20 \mathrm{mM} \mathrm{Et}{ }_{2} \mathrm{PC}(27)$. As shown in Table 1, treatment of PSTV with $20 \mathrm{mM} \mathrm{Et}_{2} \mathrm{PC}$ causes little inactivation, and even incubation with $50 \mathrm{mM} \mathrm{Et}_{2} \mathrm{PC}$ has only a slight effect on the level of PSTV infectivity. Genomic single-stranded CMV RNA, however, is readily inactivated by $20 \mathrm{mM} \mathrm{Et}_{2} \mathrm{PC}$ (Table 1).

Infectivity of the scrapie agent, which had been largely lost because of treatment with $\mathrm{Et}_{2} \mathrm{PC}$, could be restored almost completely by exposure of the treated agent to hydroxylamine (27). It was, therefore, of interest to examine whether the slight loss of infectivity resulting from treatment of PSTV with $\mathrm{Et}_{2} \mathrm{PC}$ could be similarly reversed by subsequent treatment with hydroxylamine. As shown in Table 2, such a reversal was not obtained. On the contrary, exposure of PSTV to hydroxylamine alone resulted in considerable loss of infectivity [whereas such treatment had no effect on scrapie infectivity (27)] and treatment with hydroxylamine of previously $\mathrm{Et}_{2} \mathrm{PC}$-treated preparations led to further conspicuous reductions of infectivity (Table 2), again demonstrating a clear difference between the scrapie agent and PSTV. Other experiments (data not shown) revealed that infectivity of $\mathrm{Et}_{2} \mathrm{PC}$-inactivated $\mathrm{CMV} \mathrm{RNA}$ could

Table 1. Treatment of PSTV, CMV RNA, and the scrapie agent with $\mathrm{Et}_{2} \mathrm{PC}$

\begin{tabular}{|c|c|c|c|c|}
\hline \multirow{3}{*}{$\begin{array}{c}\mathrm{Et}_{2} \mathrm{PC} \\
\mathrm{mM}\end{array}$} & \multicolumn{4}{|c|}{ Infectivity } \\
\hline & \multicolumn{2}{|c|}{$\begin{array}{c}\text { PSTV, } \\
\text { Infectivity index } \\
\end{array}$} & \multirow{2}{*}{$\begin{array}{c}\text { CMV RNA, } \\
\text { infectivity } \\
\text { index }\end{array}$} & \multirow{2}{*}{$\begin{array}{c}\text { Scrapie agent } \\
\log \left(\mathrm{ID}_{50} / \mathrm{ml}\right)\end{array}$} \\
\hline & Exp. I & Exp. II & & \\
\hline 0 & 553 & 343 & 115 & $5.9 \pm 0.28$ \\
\hline 20 & 556 & 298 & 0 & $3.0 \pm 0.15$ \\
\hline 50 & 437 & 288 & 0 & \\
\hline
\end{tabular}

Partially purified PSTV or purified genomic CMV RNA was dissolved in $0.06 \mathrm{M}$ sodium phosphate buffer, $\mathrm{pH} 7.0$. Freshly prepared aqueous $\mathrm{Et}_{2} \mathrm{PC}$ was then added to each preparation to give the desired final $\mathrm{Et}_{2} \mathrm{PC}$ concentrations. All samples were mixed well and incubated at room temperature for $30 \mathrm{~min}$. Data for the scrapie agent are from ref. 27; \pm indicates SEM.
Table 2. Treatment of PSTV with $\mathrm{Et}_{2} \mathrm{PC}$ followed by hydroxylamine

\begin{tabular}{rccc}
\hline & \multicolumn{3}{c}{ Infectivity index } \\
\cline { 2 - 4 } $\mathrm{Et}_{2} \mathrm{PC}$, & $0 \mathrm{M}$ & $0.1 \mathrm{M}$ & $0.5 \mathrm{M}$ \\
$\mathrm{mM}$ & $\mathrm{NH}_{2} \mathrm{OH}$ & $\mathrm{NH}_{2} \mathrm{OH}$ & $\mathrm{NH}_{2} \mathrm{OH}$ \\
\hline 0 & 474 & 284 & 250 \\
0.1 & 560 & 96 & 104 \\
1.0 & 456 & 288 & 121 \\
10.0 & 417 & 117 & 107 \\
\hline
\end{tabular}

Aliquots of partially purified PSTV in $0.06 \mathrm{M}$ sodium phosphate buffer, $\mathrm{pH} 7.0$, were incubated at $25^{\circ} \mathrm{C}$ for $2 \mathrm{hr}$ with freshly prepared aqueous $\mathrm{Et}_{2} \mathrm{PC}$ at the final concentrations shown. Hydroxylamine $\left(\mathrm{NH}_{2} \mathrm{OH}\right)$ was then added as indicated and the preparations were incubated at $25^{\circ} \mathrm{C}$ for an additional $16 \mathrm{hr}$. One-to-ten dilutions were bioassayed on tomato plants and the infectivity index of each sample was calculated.

also not be restored by subsequent treatment with hydroxylamine.

Psoralens are linear tricyclic furocoumarin derivatives that readily penetrate animal and bacterial cellular membranes as well as viral envelopes $(28,29)$. Once inside a virus, the psoralens preferentially bind to its nucleic acid (29). Upon irradiation at $360 \mathrm{~nm}$, psoralen-nucleic acid adducts are formed. The adducts block transcription from viral nucleic acid and thus virus replication $(30,31)$. Recent results show that incubation of highly enriched scrapie preparations with several psoralens under a variety of conditions has no effect on the infectivity titer of the preparations (unpublished data).

Table 3 shows that, in contrast to the scrapie agent, PSTV is readily inactivated when irradiated in the presence of relatively small amounts of a psoralen derivative (AMT).

Incubation of nucleic acids at elevated temperature in the presence of $2 \mathrm{mM} \mathrm{Zn}{ }^{2+}$ results in complete hydrolysis of RNA to mononucleotides and considerable hydrolysis of DNA (32, 33). Table 4 shows that, in contrast to PSTV, which was completely inactivated after incubation for $1 \mathrm{hr}$ with $2 \mathrm{mM} \mathrm{Zn}^{2+}$ at $65^{\circ} \mathrm{C}$, infectivity of the scrapie agent was unaffected by incubation under these conditions for as long as $24 \mathrm{hr}$.

Exposure of PSTV and the scrapie agent to mildly alkaline conditions disclosed that the latter is far more sensitive to this treatment than is PSTV (Table 5). At pH 10, PSTV infectivity was reduced at most to $1 / 10$, whereas under identical conditions the scrapie agent titer was reduced to $10^{-5}$.

Exposure of the scrapie agent to the chaotropic ion $\mathrm{SCN}^{-}$, followed by freezing at $-20^{\circ} \mathrm{C}$, resulted in inactivation of the agent (34), whereas exposure of PSTV under identical conditions had no effect on the infectivity of the viroid (Table 6). The nonchaotropic salt $\mathrm{KCl}$ had no effect on either agent.

Table 3. Treatment of PSTV and the scrapie agent with a psoralen derivative (AMT)

\begin{tabular}{|c|c|c|c|}
\hline \multirow{2}{*}{$\begin{array}{l}\text { AMT, } \\
\mu \mathrm{g} / \mathrm{ml}\end{array}$} & \multicolumn{2}{|c|}{$\begin{array}{l}\text { PSTV, infected/ } \\
\text { inoculated plants }\end{array}$} & \multirow{2}{*}{$\begin{array}{l}\text { Scrapie agent, } \\
\log \left(\mathrm{ID}_{50} / \mathrm{ml}\right)\end{array}$} \\
\hline & Exp. I & Exp. II & \\
\hline 0 & $4 / 5$ & $5 / 5$ & $6.2 \pm 0.07$ \\
\hline 1 & $2 / 5$ & $4 / 5$ & $6.2 \pm 0.18$ \\
\hline 10 & & & $6.5 \pm 0.11$ \\
\hline 50 & $0 / 5$ & $0 / 5$ & $6.1 \pm 0.22$ \\
\hline 250 & $0 / 5$ & $0 / 5$ & $6.6 \pm 0.30$ \\
\hline
\end{tabular}

Mixtures of purified PSTV or highly enriched preparations of the scrapie agent (both in $60 \mathrm{mM}$ Tris acetate, $\mathrm{pH} 8.3$, containing $1 \mathrm{mM}$ EDTA and $0.2 \%$ Sarkosyl) and various concentrations of AMT were irradiated at room temperature for $90 \mathrm{~min}$. Results with scrapie agent are presented \pm SEM, as they are in Tables 4-6. 
Table 4. Treatment of PSTV and the scrapie agent with $\mathrm{Zn}^{2+}$

\begin{tabular}{|c|c|c|c|c|}
\hline \multirow{2}{*}{$\begin{array}{c}\text { Time } \\
\text { at } 65^{\circ} \mathrm{C} \text {, } \\
\mathrm{hr}\end{array}$} & \multicolumn{2}{|c|}{$\begin{array}{c}\text { PSTV, } \\
\text { infectivity index }\end{array}$} & \multicolumn{2}{|c|}{$\begin{array}{l}\text { Scrapie agent, } \\
\log \left(\mathrm{ID}_{50} / \mathrm{ml}\right)\end{array}$} \\
\hline & $\begin{array}{l}0 \mathrm{mM} \\
\mathrm{Zn}^{2+}\end{array}$ & $\begin{array}{c}2.0 \mathrm{mM} \\
\mathrm{Zn}^{2+}\end{array}$ & $\begin{array}{l}0 \mathrm{mM} \\
\mathrm{Zn}^{2+} \\
\end{array}$ & $\begin{array}{c}2.0 \mathrm{mM} \\
\mathrm{Zn}^{2+} \\
\end{array}$ \\
\hline 0 & 279 & 284 & $7.3 \pm 0.03$ & \\
\hline 0.17 & 306 & 179 & & \\
\hline 1.0 & 313 & 0 & & \\
\hline 2.0 & & & $8.0 \pm 0.26$ & $7.0 \pm 0.16$ \\
\hline 4.0 & 290 & 0 & $7.3 \pm 0.37$ & $7.1 \pm 0.16$ \\
\hline 24.0 & & & $7.1 \pm 0.23$ & $7.1 \pm 0.13$ \\
\hline
\end{tabular}

Zinc chloride was added to partially purified PSTV as indicated, and the preparation was neutralized with $10 \mathrm{mM}$ sodium borate buffer and incubated. Another portion of PSTV was brought to $\mathrm{pH} 5.0$ with $2 \mathrm{mM}$ $\mathrm{HCl}$, neutralized with $10 \mathrm{mM}$ sodium borate buffer, and incubated. To a highly enriched preparation of the scrapie agent in $10 \mathrm{mM} \mathrm{NaNO}_{3}$, $\mathrm{pH} \mathrm{7}$, containing $0.2 \% \mathrm{NaDodSO}_{4}$, zinc nitrate was added as indicated and the preparation was incubated at $65^{\circ} \mathrm{C}$.

\section{DISCUSSION}

Previous results, as well as those reported here, demonstrate that, with respect to several criteria, properties of PSTV are exactly opposite those of the scrapie agent (Table 7). The scrapie agent is resistant to RNase degradation at concentrations as high as $500 \mu \mathrm{g} / \mathrm{ml}$ for up to $30 \mathrm{hr}$ at $37^{\circ} \mathrm{C}$, whereas PSTV is exquisitely sensitive to RNase (35). In the case of viroids, hydrolysis of a single phosphodiester bond probably results in inactivation. Both the scrapie agent and the PSTV are resistant to degradation by DNases $(20,35)$.

In highly enriched preparations of the scrapie agent, proteinase $\mathrm{K}$ and trypsin greatly reduce the titer of the agent (20). In contrast, proteases have no effect on the infectivity of PSTV (6). It is noteworthy that there are many examples of proteins that retain their biological activities after limited proteolysis (20). In the case of the scrapie agent we do not know how many peptide bonds must be cleaved for a reduction of infectivity to be observed.

Extensive inactivation of the scrapie agent occurs upon carbethoxylation by $\mathrm{Et}_{2} \mathrm{PC}(27)$. In contrast, PSTV is only slightly inactivated by $\mathrm{Et}_{2} \mathrm{PC}$, yet, as shown by the total inactivation of a single-stranded RNA (CMV RNA), $\mathrm{Et}_{2} \mathrm{PC}$ was present in fully active form in these experiments. The slight inactivation of PSTV after treatment with $\mathrm{Et}_{2} \mathrm{PC}$ confirms an earlier study in which another viroid (citrus exocortis viroid) was shown to be far more resistant to inactivation by $\mathrm{Et}_{2} \mathrm{PC}$ than was a viral single-stranded RNA (cowpea mosaic virus RNA) (36).

Presumably, the target of the chemical modification that leads to inactivation of the scrapie agent by $\mathrm{Et}_{2} \mathrm{PC}$ is a histidine residue, although other nucleophilic amino acid residues might also be targets. The restoration of infectivity upon decarbethoxylation with hydroxylamine strongly favors a proteinaceous target within the agent. Hydroxylamine generally has little ef-

Table 5. Alkali treatment of PSTV and the scrapie agent

\begin{tabular}{rcc}
\hline $\mathrm{pH}$ & $\begin{array}{c}\text { PSTV, } \\
\text { infectivity } \\
\text { index }\end{array}$ & $\begin{array}{c}\text { Scrapie agent, } \\
\log \left(\mathrm{ID}_{50} / \mathrm{ml}\right)\end{array}$ \\
\hline 7.0 & 392 & $8.3 \pm 0.28$ \\
9.0 & 329 & $8.3 \pm 0.25$ \\
9.5 & 293 & $3.4 \pm 0.20$ \\
10.0 & 257 & \\
\hline
\end{tabular}

Partially purified PSTV or highly enriched preparations of the scrapie agent were adjusted to the $\mathrm{pH}$ values indicated, incubated for $1 \mathrm{hr}$ at $4^{\circ} \mathrm{C}$, neutralized, and then bioassayed.
Table 6. Exposure of PSTV and the scrapie agent to KSCN

\begin{tabular}{lcccc}
\hline \multicolumn{2}{c}{ Treatment } & & \\
\hline $\begin{array}{c}\text { Salt } \\
(1 \mathrm{M})\end{array}$ & $\begin{array}{c}\text { Duration of } \\
\text { freezing, } \\
\text { days }\end{array}$ & $\begin{array}{c}\text { PSTV, } \\
\text { infectivity } \\
\text { index }\end{array}$ & $\begin{array}{c}\text { Scrapie agent, } \\
\log \left(\mathrm{ID}_{50} / \mathrm{ml}\right)\end{array}$ \\
\hline- & 2 & & $8.1 \pm 0.12$ \\
$\mathrm{KCl}$ & 2 & 381 & $5.7 \pm 0.29$ \\
$\mathrm{KSCN}$ & 2 & 324 & $8.9 \pm 0.19$ \\
- & 21 & 342 & $8.9 \pm 0.22$ \\
$\mathrm{KCl}$ & 21 & 380 & $3.8 \pm 0.14$ \\
$\mathrm{KSCN}$ & 21 & & 380 \\
\hline
\end{tabular}

Partially purified preparations of either agent in $0.02 \mathrm{M}$ Tris acetate, $\mathrm{pH} 8.3$, were exposed for $2 \mathrm{hr}$ at $4^{\circ} \mathrm{C}$ to either $\mathrm{KCl}$ or KSCN. The preparations were then frozen at $-20^{\circ} \mathrm{C}$, stored as indicated, thawed, and bioassayed.

fect on unmodified proteins but readily modifies the structure of nucleic acids (37). Indeed, hydroxylamine, instead of restoring full infectivity of carbethoxylated PSTV, further inactivated it. Furthermore, exposure of non-Et ${ }_{2}$ PC-treated PSTV to hydroxylamine alone also led to partial inactivation, whereas exposure of untreated scrapie agent to hydroxylamine had no effect on infectivity (27).

Psoralens penetrate the proteinaceous coats of most viruses, bind to the nucleic acid genomes of the viruses, and form covalent adducts with the genomes upon photoactivation. These stable photoadducts block virus replication $(30,31)$. Under conditions in which psoralens react relatively specifically with nucleic acids, these photoactivated molecules failed to alter scrapie agent infectivity. One psoralen derivative, AMT, failed to inactivate the scrapie agent at concentrations as high as $500 \mu \mathrm{g} /$ $\mathrm{ml}$. Under the same conditions, PSTV was completely inactivated after exposure to $50 \mu \mathrm{g} / \mathrm{ml}$ of AMT, again demonstrating the basic dissimilarity of the two pathogens.

Early studies had shown that the scrapie agent is sensitive to phenol; invariably almost complete titer losses were recorded after treatment with phenol (38). In contrast, phenol extraction has been extensively used in the isolation and purification of PSTV, without detectable loss of infectivity (23).

Conflicting reports have been published concerning sensitivity of the scrapie agent to $\mathrm{NaDodSO}_{4}(19,21,39,40)$. In our hands, low concentrations of $\mathrm{NaDodSO}_{4}(<1 \%)$ activate or have no effect upon the scrapie agent (19). Activation presumably results from disaggregation of the agent. At high concentrations $(\geq 1 \%)$, however, the agent is readily inactivated $(19)$. To date, we have been unable to renature the agent upon removal of

Table 7. Comparison of the stabilities of viroids and prions

\begin{tabular}{lccc}
\hline \multicolumn{1}{c}{ Treatment } & Concentration & PSTV & Scrapie agent \\
\hline RNase A & $0.1-100 \mu \mathrm{g} / \mathrm{ml}$ & + & - \\
DNase & $100 \mu \mathrm{g} / \mathrm{ml}$ & - & - \\
Proteinase K & $100 \mu \mathrm{g} / \mathrm{ml}$ & - & + \\
Trypsin & $100 \mu \mathrm{g} / \mathrm{ml}$ & - & + \\
$\mathrm{Et}_{2} \mathrm{PC}$ & $10-20 \mathrm{mM}$ & {$[-]$} & + \\
$\mathrm{NH}_{2} \mathrm{OH}$ & $0.1-0.5 \mathrm{M}$ & + & - \\
Psoralen (AMT) & $10-500 \mu \mathrm{g} / \mathrm{ml}$ & + & - \\
Phenol & Saturated & - & + \\
NaDodSO $_{4}$ & $1-10 \%$ & - & + \\
$\mathrm{Zn}^{2+}$ & $2 \mathrm{mM}$ & + & - \\
Urea & $3-8 \mathrm{M}$ & - & + \\
Alkali & $\mathrm{pH} \mathrm{10}$ & {$[-]$} & + \\
KSCN & $1 \mathrm{M}$ & - & + \\
\hline
\end{tabular}

See the introduction for a definition of the term "prion." -, No change; [-], small change; + , inactivation. 
$\mathrm{NaDodSO}_{4}$. In contrast, the infectivity of PSTV is unaffected by $\mathrm{NaDodSO}_{4}$.

To probe further for the presence of nucleic acid within the scrapie agent, the effect of zinc ions, which catalyze the hydrolysis of phosphodiester bonds within nucleic acids, was investigated. In the presence of $2 \mathrm{mM} \mathrm{Zn}^{2+}$, hydrolysis of RNA to mononucleotides occurs within $2 \mathrm{hr}$ at $65^{\circ} \mathrm{C}$ (33). In our experiments PSTV was indeed totally inactivated after exposure at $65^{\circ} \mathrm{C}$ to $2 \mathrm{mM} \mathrm{Zn}^{2+}$ for only $1 \mathrm{hr}$. However, incubation of the scrapie agent under these conditions for as long as $24 \mathrm{hr}$ did not lead to a measurable reduction of the infectivity titer.

Recent studies have shown that $3.0 \mathrm{M}$ urea irreversibly inactivates the scrapie agent after exposure for $3 \mathrm{hr}$ at $4^{\circ} \mathrm{C}(21)$, whereas the infectivity of PSTV is unaffected by exposure to 8 $\mathrm{M}$ urea at $4^{\circ} \mathrm{C}(41)$.

Exposure to mild alkali ( $\mathrm{pH} 10)$ similarly resulted in divergent results with the two pathogens. Although the lability of RNA in alkali is well documented (42), the conditions used resulted only in minimal inactivation of PSTV. The extreme reduction in scrapie agent titer under the same conditions suggests that a mechanism other than RNA hydrolysis is operative (34). Some proteins exhibit denaturation under the conditions used to inactivate the scrapie agent with $\mathrm{OH}^{-}(43)$.

It is interesting to note that four reagents commonly used in the isolation and purification of nucleic acids (phenol, Na$\mathrm{DodSO}_{4}, \mathrm{KSCN}$, and urea) readily inactivate the scrapie agent but leave PSTV infectivity unaltered. Presumably, such reagents inactivate the scrapie agent through protein denaturation. In contrast, four other reagents that readily inactivate nucleic acids [nucleases (either RNase or DNase), hydroxylamine, psoralens, and zinc ions] had no effect on the scrapie agent but substantially reduced PSTV infectivity.

Some of the molecular properties of viroids and prions are compared in Table 8. PSTV is composed of a single-stranded RNA molecule that is devoid of protein. No nucleic acid has been found to be associated with the scrapie agent, but protein(s) is required for infectivity. The molecular weight of PSTV has been established (7). Size determinations of the scrapie agent are complicated by its apparent heterogeneity, which presumably results from its hydrophobicity. Preliminary measurements of the agent in a disaggregated state indicate that the molecular weight may be $\leq 50,000$ and the sedimentation coefficient $\leq 2 \mathrm{~S}$, assuming a particle density of $>1.05 \mathrm{~g} / \mathrm{cm}^{3}$ (ref. 21 and unpublished observations). Further studies will be required to determine whether binding of detergent to the agent influences its sedimentation, causing it to float in one case, or giving it an erroneously large sedimentation coefficient in the other case. These observations, as well as target size estimates, provide three independent lines of evidence suggesting that the smallest forms of the infectious scrapie agent may be smaller than PSTV.

Although viroids serve as templates from which complemen-

Table 8. Some molecular properties of viroids and prions

\begin{tabular}{lll}
\hline \multicolumn{1}{c}{ Properties } & PSTV & Scrapie agent \\
\hline Nucleic acid & + & {[]$^{*}$} \\
Protein & - & + \\
Molecular weight & 127,000 & $\leq 50,000$ \\
Sedimentation coefficient, S & 6.7 & $\leq 2^{+}$ \\
$D_{37^{\ddagger}}$ at $254 \mathrm{~nm}, \mathrm{~J} / \mathrm{m}^{2}$ & 5,000 & 42,000 \\
\hline
\end{tabular}

* Denotes no nucleic acid demonstrated to date.

$+S_{\text {obs }}$ value calculated with the assumption that the particle density is $>1.05 \mathrm{~g} / \mathrm{cm}^{3}$.

$\ddagger$ Dose $\left(D_{37}\right)$ of ultraviolet light that permits $37 \%(1 / e)$ survival of the infectious particle. tary RNAs and progeny viroids are transcribed (44), there is no indication that viroids code for proteins (45). The replication mechanism of prions is unknown. The apparent small size of the scrapie agent, however, seems to preclude the presence of a genome buried within the prion that might serve as a template coding for the protein(s) of a putative capsid (21).

The small size of viroids as compared to viruses makes them 10 to 100 times more resistant to inactivation by ultraviolet irradiation at $254 \mathrm{~nm}(46)$. In contrast, the scrapie agent in partially purified, optically clear preparations has a $D_{37}$ that is 8 times greater than the $D_{37}$ for PSTV. Factors contributing to the extreme resistance of the scrapie agent include: $(i)$ its small size, (ii) the apparent absence of nucleic acid, and (iii) its ability to form aggregates.

Our results strongly support the proposition that the molecular properties of the scrapie agent are fundamentally different from those of viroids and viruses. The evidence now available appears compelling in eliminating a small, naked nucleic acid as a model for the scrapie agent; our results also seem to diminish further the likelihood that a nucleic acid, be it DNA or RNA, is an essential part of the scrapie agent. The evidence presented therefore strengthens the concept advanced by one of us that the scrapie agent represents the prototype of a class of pathogens for which the term "prion" has been proposed (21). Prions are small proteinaceous particles that resist inactivation by most procedures that modify nucleic acids. Until the particles are purified to homogeneity and the presence or absence of nucleic acid has been determined, the definition of "prion," by necessity, must be operational.

It is worth noting that, of the two classes of subviral pathogens now recognized, viroids have been identified only in plants and prions only in animals. If further work confirms this host specificity, it will be interesting to determine by what molecular mechanisms these unusual infectious agents are restricted to either plants or animals.

We thank Dennis R. Smith, Darlene Groth, Patricia Cochran, Karen Bowman, and Jocelyn Mayled for excellent technical assistance. This research was supported in part by grants from the National Institutes of Health (NS 14069 and AG 02132) and a gift from R. J. Reynolds Industries.

1. Álper, T., Haig, D. A. \& Clarke, M. C. (1966) Biochem. Biophys. Res. Commun. 22, 278-284.

2. Alper, T., Cramp, W. A., Haig, D. A. \& Clarke, M. C. (1967) Nature (London) 214, 764-766.

3. Latarjet, R. (1979) in Slow Transmissible Diseases of the Nervous System, eds. Prusiner, S. B. \& Hadlow, W. J. (Academic, New York), Vol. 2, pp. 387-408.

4. Diener, T. O. (1972) Nature (London) New Biol. 235, 218-219.

5. Diener, T. O. (1971) Virology 45, 411-428.

6. Diener, T. O. (1971) Virology 43, 75-89.

7. Sänger, H. L., Klotz, G., Riesner, D., Gross, H. J. \& Kleinschmidt, A. K. (1976) Proc. Natl. Acad. Sci. USA 73, 3852-3856.

8. Gross, H. J. \& Riesner, D. (1980) Angew. Chem. 19, 231-243.

9. Sogo, J. M., Koller, T. \& Diener, T. O. (1973) Virology 55, $70-80$.

10. McClements, W. L. \& Kaesberg, P. (1977) Virology 76, 477-484.

11. Gross, H. J., Domdey, H., Lossow, C., Jank, P., Raba, M., Alberty, H. \& Sänger, H. L. (1978) Nature (London) 273, 203-208.

12. Symons, R. H. (1981) Nucleic Acids Res. 9, 6527-6537.

13. Visvader, J. E., Gould, A. R., Bruening, G. E. \& Symons, R. H. (1982) FEBS Lett. 137, 288-292.

14. Marsh, R. F., Semancik, J. S., Medappa, K. C., Hanson, R. P. \& Rueckert, R. R. (1974) J. Virol. 13, 993-996.

15. Ward, R. L., Porter, D. D. \& Stevens, J. G. (1974) J. Virol 14, 1099-1103.

16. Marsh, R. F., Malone, T. G., Semancik, J. S., Lancaster, W. D. \& Hanson, R. P. (1978) Nature (London) 275, 146-147. 
17. Malone, T. G., Marsh, R. F., Hanson, R. P. \& Semancik, J. S. (1979) Nature (London) 278, 575-576.

18. Prusiner, S. B., Groth, D. F., Bildstein, C., Masiarz, F. R. McKinley, M. P. \& Cochran, S. P. (1980) Proc. Natl. Acad. Sci. USA 77, 2984-2988.

19. Prusiner, S. B., Groth, D. F., Cochran, S. P., Masiarz, F. R., McKinley, M. P. \& Martinez, H. M. (1980) Biochemistry 19, 4883-4891.

20. Prusiner, S. B., McKinley, M. P., Groth, D. F., Bowman, K. A. Mock, N. I., Cochran, S. P. \& Masiarz, F. R. (1981) Proc. Natl. Acad. Sci. USA 78, 6675-6679.

21. Prusiner, S. B. (1982) Science 216, 136-144.

22. Prusiner, S. B., Cochran, S. P., Groth, D. F., Downey, D. E., Bowman, K. A. \& Martinez, H. M. (1982) Ann. Neurol. 11, 353-358.

23. Diener, T. O., Hadidi, A. \& Owens, R. A. (1977) in Methods in Virology, eds. Maramorosch, K. \& Koprowski, H. (Academic, New York), Vol. 6, pp. 185-217.

24. Raymer, W. B. \& Diener, T. O. (1969) Virology 37, 343-350.

25. Miles, E. W. (1977) Methods Enzymol. 47, 431-442.

26. Ehrenberg, L., Fedorcsák, I. \& Solymosy, F. (1976) Prog. Nucleic Acid Res. Mol. Biol. 16, 189-262.

27. McKinley, M. P., Masiarz, F. R. \& Prusiner, S. B. (1981) Science 214, 1259-1261.

28. Issacs, S. T., Shen, C. J., Hearst, J. E. \& Rapoport, H. (1977) Biochemistry 16, 1058-1064.

29. Johnston, B. H., Johnson, M. A., Moore, C. B. \& Hearst, J. E. (1977) Science 197, 906-908.

30. Hearst, J. E. \& Thiry, L. (1977) Nucleic Acids Res. 4, 1339-1348.

31. Hanson, C. V., Riggs, J. L. \& Lennette, E. H. (1978) J. Gen. Virol. 40, 345-358.
32. Butzow, J. L. \& Eichhorn, G. L. (1965) Biopolymers 3, 95-107.

33. Butzow, J. L. \& Eichhorn, G. L. (1975) Nature (London) 254, 358-359.

34. Prusiner, S. B., Groth, D. F., McKinley, M. P., Cochran, S. P., Bowman, K. A. \& Kasper, K. C. (1981) Proc. Natl. Acad. Sci. USA 78, 4606-4610.

35. Diener, T. O. \& Raymer, W. B. (1969) Virology 37, 351-366

36. Semancik, J. S. \& Weathers, L. G. (1972) Virology 47, 456-466.

37. Phillips, J. H. \& Brown, D. M. (1967) Prog. Nucleic Acid Res. Mol. Biol. 7, 349-368.

38. Hunter, G. D. \& Millson, G. C. (1967) J. Comp. Pathol. 77, 301-307.

39. Millson, G. C., Hunter, G. D. \& Kimberlin, R. H. (1976) in Slow Virus Diseases of Animals and Man, ed. Kimberlin, R. H. (Elsevier/North-Holland, New York), pp. 243-266.

40. Millson, G. C. \& Manning, E. J. (1979) in Slow Transmissible Diseases of the Nervous System, eds. Prusiner, S. B. \& Hadlow, W. J. (Academic, New York), Vol. 2, pp. 409-424.

41. Owens, R. A., Erbe, E., Hadidi, A., Steere, R. L. \& Diener, T. O. (1977) Proc. Natl. Acad. Sci. USA 74, 3859-3863.

42. Bock, R. M. (1967) Methods Enzymol. 12, 218-221.

43. Whitaker, J. R. (1980) in Chemical Deterioration of Proteins, eds. Whitaker, J. R. \& Fujimaki, M. (Am. Chem. Soc. Sympos. 123, Wash., DC) pp. 147-166.

44. Owens, R. A. \& Diener, T. O. (1982) Proc. Natl. Acad. Sci. USA 79, 113-117.

45. Diener, T. O. (1981) Ann. Rev. Plant Physiol. 32, 313-325.

46. Diener, T. O., Schneider, I. R. \& Smith, D. R. (1974) Virology 57, 577-581. 